\title{
Raynaud's phenomenon and pulmonary arterial hypertension: a case report
}

\author{
(D) Maja Šipić*, \\ DSnežana Lazić, \\ DBiljana Krdžić, \\ (D) Slavica Pajović, \\ (1D Kristina Bulatović \\ Faculty of Medical Science \\ University of Pristina, \\ Kosovska Mitrovica, Kosovo
}

KEYWORDS: Raynaud's phenomenon, pulmonary arterial hypertension. CITATION: Cardiol Croat. 2018;13(11-12):375. | https://doi.org/10.15836/ccar2018.375

*ADDRESS FOR CORRESPONDENCE: Maja Šipić, Faculty of Medical Science University of Prishtina, Anri Dinana b.b., 38220 Kosovska Mitrovica, Kosovo. / Phone: +381-64-1267-817 / E-mail: drsipic@yahoo.com

ORCID: Maja Šipić, https://orcid.org/0000-0003-4173-1224 • Snežana Lazić, https://orcid.org/0000-0001-6362-3713 Biljana Krdžić, https://orcid.org/0000-0002-4756-4001 • Slavica Pajović, https://orcid.org/0000-0001-8805-2566 Kristina Bulatović, https://orcid.org/0000-0002-3488-6765

IIIIIIIIIIIIIIIIIIIIIIIIIIIIIIIIIIIIIIIIIIIIIIIIIIIIIIIIIIIIIIIIIIIIIIIIIIIIIIIIIIIIIIIIIIIIIIIIIIIIIIIII

Introduction: Pulmonary arterial hypertension (PAH) is a group 1 pulmonary circulation disease. It is associated with severe arterial remodeling, increase in pulmonary vascular resistance (PVR), precapillary pulmonary hypertension, systemic procoagulant condition, and lastly, with right heart failure. Increased blood viscosity, oxidative stress, Raynaud's phenomenon (RF) intermittent vasospasms contribute to PAH. The incidence of primary RF and PAH is insufficiently known. ${ }^{1,2}$

Case report: 49-year-old male, first hospitalization. Principal complaints: extreme fatigue on the slightest effort and ankle and abdominal edema for the past three months. For the past several years, he noticed paleness of his fingers at exposure to cold, but did not consider this to be significant. Eupneic at rest, acyanotic, emphasized P2, with systolic murmur with point of maximum intensity in the left parasternal area; preserved radial and ulnar pulsations on both sides; discrete ankle edema. BP 110/70 mmHg. ECG - sinus rhythm, HR 100 beats per minute, right axis deviation, negative T in V1-4. Increased levels of bilirubin, Na, LDH, CK and CK-MB. NT-proBNP 3830 pg/mL. Echocardiography - LV shows normal ESD and EDD; EF 40\%; without segmental kinetic disturbances. DV:LV>1.06; TAPSE 13 mm; PaccT 61 ms; RVSP 70 mmHg; TR 3 +. Thoracic HRCT shows small zones of ground glass opacity, without lesions of lung interstitium or airways. Right heart catheterization - confirmed precapillary pulmonary hypertension; mPAP 48 mmHg; PVR 7 WU; CI 2.5. Perfusion scintigraphy indicated small perfusion defects. Highly positive ANA in Hep 2 cells. Pulmonary function - FVC 113.20; FEV1101.30; TTGV\% 153.20; pO2 8.59 kPa; pCO2 3.76 kPa; sO2 92.8\%; pH 7.43. 6 Min WDT Borg 4.

Conclusion: The diagnosis of severe PAH in our patient was delayed due to a long oligosymptomatic period. PH evaluation in the presence of Raynaud's phenomenon is necessary.
RECEIVED:

October 26, 2018

ACCEPTED:

November 5, 2018

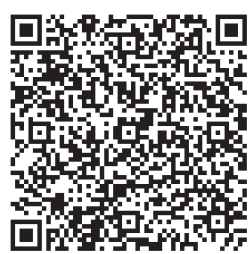

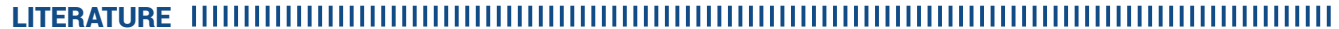

1. Hall FC. Cold hands-strained heart? Advances in the management of Raynaud's phenomenon and pulmonary hypertension. Arthritis Res Ther. 2005;7(3):126-8. https://doi.org/10.1186/ar1755

2. Bakst R, Merola JF, Franks AG Jr, Sanchez M. Raynaud's phenomenon: pathogenesis and management. J Am Acad Dermatol. 2008 0ct;59(4):633-53. https://doi.org/10.1016/j.jaad.2008.06.004 